Ambiente \& Água - An Interdisciplinary Journal of Applied Science
ISSN 1980-993X - doi:10.4136/1980-993X
www.ambi-agua.net
E-mail: ambi.agua@gmail.com

\title{
Determination of toxicity assays, trophic state index, and physicochemical parameters on Piracicaba River and Itapeva Stream
}

\author{
doi: 10.4136/ambi-agua.1387 \\ Received: 28 Apr. 2014; Accepted: 02 Mar. 2015

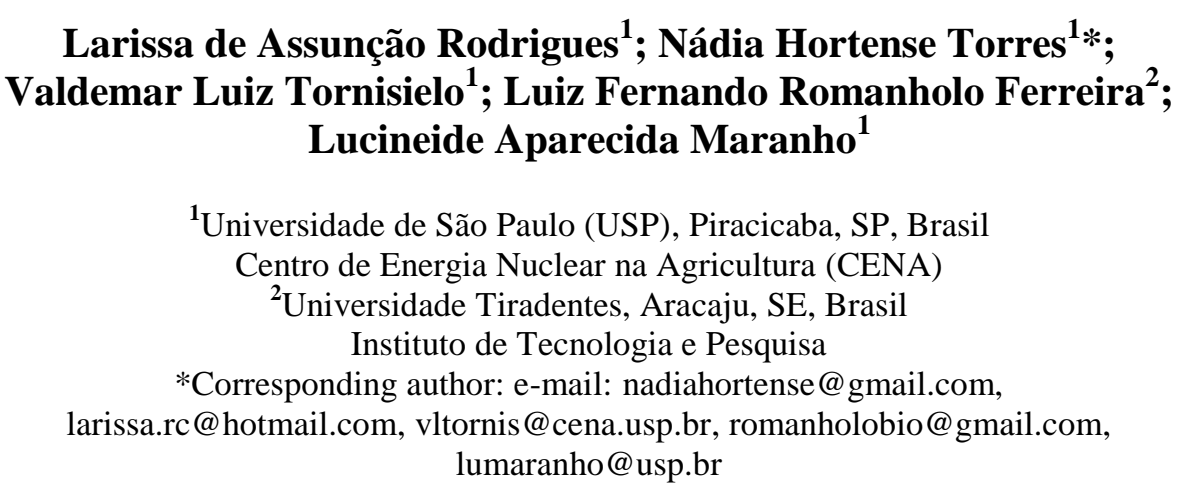

\section{ABSTRACT}

Anthropogenic activity has a great impact on aquatic environments, causing changes in biodiversity and the environment. In an attempt to determine pollution levels, we established physicochemical parameters, a trophic state index and toxicity assays. The Piracicaba River is an important water body that receives xenobiotic waste from industry, domestic activities and agriculture. These pollutants are released directly into the river or by streams like Itapeva Stream, which discharges into the river. The goals of this work were to analyze the toxicity factor for Daphnia magna $\left(\mathrm{TF}_{\mathrm{D}}\right)$, trophic state index (TSI), $\mathrm{pH}$, conductivity, temperature and dissolved oxygen in the Piracicaba River and in the Itapeva Stream from one monthly collection in the months of May, June and August 2011. In the Piracicaba River was not found toxicity, while in May, June and August the $\mathrm{TF}_{\mathrm{D}}$ was 1, 8 and 1, respectively. The TSI varied from mesotrophic to eutrophic in the river and in the stream from ultraoligotrophic to mesotrophic. The medium of conductivity for the Itapeva Stream was $479.5 \mu{\mathrm{S} . \mathrm{cm}^{-1}}^{-}$and for the Piracicaba River was $219.8 \mu \mathrm{S} . \mathrm{cm}^{-1}$. The dissolved oxygen in the Piracicaba River varied from 6.89 to1 $1.36 \mathrm{mg} . \mathrm{L}^{-1}$ and in the Itapeva Stream from 0.92 to $6.31 \mathrm{mg} . \mathrm{L}^{-1}$. Based upon the results, both hydric bodies were eutrophic, and the Itapeva Stream was classified as unsuitable for maintaining aquatic life.

Keywords: aquatic life, ecotoxicological tests, environmental contamination, toxicity factor.

\section{Determinação de ensaios de toxicidade, índice de estado trófico e parâmetros físico-químicos no Rio Piracicaba e no Córrego Itapeva}

\section{RESUMO}

Atividades antrópicas causam grandes impactos em ambientes aquáticos, provocando alterações na biodiversidade e no ambiente. Na tentativa de determinar níveis de poluição foram definidos parâmetros físicos e químicos, índice de estado trófico e testes de toxicidade 
com organismos. O Rio Piracicaba é um importante corpo d'agua que recebe despejos de xenobióticos de origem agropecuária, industrial e doméstica. Estes poluentes são lançados de forma direta ou são provenientes de córregos que deságuam nesse rio, como o córrego Itapeva. Os objetivos deste trabalho foram analisar o fator de toxicidade para Daphnia magna $\left(\mathrm{FT}_{\mathrm{D}}\right.$ ), índice de estado trófico (IET), $\mathrm{pH}$, condutividade, temperatura e oxigênio dissolvido no Rio Piracicaba e córrego Itapeva a partir de uma coleta mensal nos meses de maio a agosto de 2011. No Rio Piracicaba não foi encontrada toxicidade, e nos meses de maio, junho e agosto, os $\mathrm{FT}_{\mathrm{D}}$ foram de 1, 8 e 1, respectivamente. A IET variou de mesotrófico a eutrófico no Rio e no Córrego de ultraoligotrófico a mesotrófico. A condutividade média para o Córrego Itapeva foi de $479,5 \mu \mathrm{S} . \mathrm{cm}^{-1}$ e para o Rio Piracicaba foi de $219,8 \mu \mathrm{S} . \mathrm{cm}^{-1}$. O oxigênio dissolvido no Rio Piracicaba variou de 6,89 a $11,36 \mathrm{mg} . \mathrm{L}^{-1}$ e no Córrego Itapeva de 0,92 a $6,31 \mathrm{mg} . \mathrm{L}^{-1}$. Com base nos resultados, ambos os corpos hídricos apresentavam-se no momento como eutróficos, e o Córrego do Itapeva foi classificado como impróprio para a manutenção da vida aquática.

Palavras-chave: contaminação ambiental, fator de toxicidade, testes ecotoxicológicos, vida aquática.

\section{INTRODUCTION}

Water is important for the existence of life on the planet. It acts as a universal solvent, as well as a carrier of gases, elements and substances that are essential for animals and plants. A good example is the hydrogen present in water, which is the source for electrons in photosynthesis (Tundisi and Tundisi, 2008).

According to Esteves (1998), the importance of water and its physical states were known for centuries before Christ. The hydrologic cycle is characterized by transport to the ocean through precipitation, and surface and groundwater flow. Rivers and lakes are important reservoirs of fresh water on continents. According Tundisi and Tundisi (2008), Brazil has between 12 and $16 \%$ of the earth's fresh water; however, the water is distributed unequally throughout its territory.

Human activities impact heavily upon terrestrial and aquatic environments. Some examples are dams, intensive land use, pesticide application and the removal of riparian vegetation (Esteves, 1988). Most importantly, during the nineteenth century increased industrialization and a population boom necessitated the increased production of consumer goods and food. This led to the increased release of industrial, agricultural and domestic wastes in water bodies (Zagatto and Bertoletti, 2006). These impacts, among others, may result in changes in biodiversity, eutrophication and biological cycles (Esteves, 1988). Excessive amounts of nutrients in lakes or other bodies of water, frequently due to runoff from the land, cause a dense growth of plant life and the death of animal life due to a lack of oxygen.

Eutrophication is a process that occurs due to the excessive richness of nutrients such as nitrogen and phosphorus in rivers, lakes and reservoirs. It is usually caused or accelerated by land runoff or by the discharge of domestic, industrial and agricultural sewage. The consequences of eutrophication are an increase in biomass, changes in biodiversity and dissolved oxygen levels, decreased water transparency and algae increase. The latter can prevent the passage of light, increasing the content of organic matter and compromising aquatic systems (Toniollo et al 1996; Knie and Lopes, 2004; Tundisi and Tundisi, 2008). It may also result in the eventual growth of toxic cyanobacteria (Maranho and Nieweglowski, 1995). To establish levels of eutrophication, the São Paulo State Environmental Technology Company, CETESB, implemented the Trophic State Index (TSI) that classifies water bodies as ultraoligotrophic, oligotrophic, mesotrophic, eutrophic, supereutrophic and hypereutrophic (Cetesb, 2007). 
Identifying the quality of water is also necessary to determine physicochemical variables such as temperature, conductivity, $\mathrm{pH}$ and dissolved oxygen, among others (Toniollo et al., 1996).

The constant dumping of pollutants into aquatic environments stimulated researchers' interest in environmental issues. Starting in the 1970s, sophisticated aquatic organism systems were developed to test toxicity. These test systems ensured practicality, reliability and reproducible results. The first organisms to be used in these tests systems were fish eggs, larvae and then micro-crustaceans. Also, to ensure protection of aquatic life, a water quality criterion was established (Zagatto and Bertoletti, 2006).

The Piracicaba River has a total area of $12568.72 \mathrm{~km}^{2}$, and is an important water body in the state of São Paulo. Along its course it receives discharges of xenobiotic domestic, industrial and agricultural waste, since it is common to find sugarcane plantations along its margins as well as livestock such as cattle and swine. The Piracicaba River runs through several cities, including Piracicaba, which has a population of 364,872 and a growth rate of $1.95 \%$ (COBRAPE, 2011).

Many streams are used for the indirect discharge of sewage into the Piracicaba River, including the Itapeva Stream, which is located in the city of Piracicaba. Its watershed is fully urbanized and located in the most populated areas of the city such as Centro and Cidade Alta (Molin et al., 2007).

The micro-crustacean Daphnia magna Staus, 1820 (Cladocera, Crustacea), feeds itself by filtering organic material, especially microalgae. This organism is useful for toxicity testing because it has features such as easy laboratory handling and maintenance with no great expense. It possesses a short life cycle and reproduces by parthenogenesis. The offspring are genetically identical, ensuring uniformity in testing (Knie and Lopes, 2004). According to the technical note ABNT NBR 12713:2003 (ABNT, 2003), this micro-crustacean is the standard organism for eco-toxicological testing.

The objectives of this study were to analyze the factor of toxicity of D. magna, the Trophic State Index (TSI), pH, conductivity, temperature and dissolved oxygen (DO), in four water samples collected from the Itapeva Stream and the Piracicaba River between May and August 2011.

\section{MATERIALS AND METHODS}

Sampling was performed preferentially from eleven to twelve o'clock according to NBR/ISO 17025 (ABNT, 2001), using a bucket tied to a rope and placed in the river current. Bottles of $1 \mathrm{~L}$. capacity were used to store the water samples. Polyethylene bottles were used to collect samples for acute toxicity testing. Amber glass bottles were used to determine the chlorophyll $\alpha$ and physiochemical parameters. The bottles were washed three times with the river water before being filled with samples. Samples were collected once a month (within the first 15 days of the month), and points of collection were located at the output of the Itapeva Stream (left border - Mirante bridge) S22 $42{ }^{\prime} 52.5^{\prime \prime}$ and W47 $39^{\prime} 00.8^{\prime \prime}$ (point which flows into Piracicaba river).

As soon as the samples were brought to the Aquatic Ecotoxicology Laboratory at the Center for Nuclear Energy in Agriculture (CENA/USP, Piracicaba-SP), determination of chlorophyll $\alpha$ was performed. The samples were shaken vigorously and transferred to $200 \mathrm{~mL}$ flasks. These samples were then filtered through a vacuum pump using cellulose filters of $28 \mathrm{~mm}$ diameter. After refrigeration for 24 hours at $-18^{0} \mathrm{C}, 10 \mathrm{~mL}$ of $90 \%$ acetone was added to the samples and the samples were maintained at a temperature of $13^{\circ} \mathrm{C}$. After 24 hours, the samples were centrifuged for $20 \mathrm{~min}$. at $3500 \mathrm{rpm}$, the supernatant was removed and volume was supplemented to $10 \mathrm{ml}$ with $90 \%$ acetone. A chlorophyll $\alpha$ concentration was 
performed in a HACH DR5000 spectrophotometer with wavelengths of $630 \mathrm{~nm}$ to absorb chlorophyll and of $750 \mathrm{~nm}$ for other pigments and suspensions. The entire procedure was performed in minimal ambient light to avoid the photo-degradation of chlorophyll.

According to the rules of Cetesb (2007), the Trophic State Index (IET) was calculated following the equation for chlorophyll $\alpha$ (Equation 1):

$$
\operatorname{IET}(\mathrm{CL})=10 \times \frac{6-0,7-0,6(\ln C L)}{\ln 2}-20
$$

where:

$\mathrm{CL}=$ chlorophyll $\alpha$ concentration measured at surface water, expressed in $\mu \mathrm{g} . \mathrm{L}^{-1}$

$\ln =$ natural logarithm

The amber bottle samples were distributed in $200 \mathrm{~mL}$ beakers for physiochemical analyzes. The YSI -55 oximeter was used to measure the amount of dissolved oxygen. The portable $\mathrm{pH}$ meter MPA - 270 from Scientific Action was used for $\mathrm{pH}$ analysis. Conductivity was measured by the MCA - 150 unit, also from Scientific Action.

Cultures of micro-crustaceans that were used in bioassays to determine the toxicity factor were maintained in an incubator with a temperature of $20 \pm 2{ }^{\circ} \mathrm{C}$ and a photoperiod of 16/8 hours light, as described by Knie and Lopes (2004). The medium M4 was prepared with purified water and essential salts, trace elements and vitamins as described in Elendt and Bias (1990). The $\mathrm{pH}$ was $7.8 \pm 0.2$ with hardness adjusted to the national natural soft water conditions of $70 \pm 80 \mathrm{mg} . \mathrm{L}^{-1} \mathrm{CaCO}_{3}$ (Maranho and Niewegłowski, 1995). The media remained for 24 hours under aeration for subsequent consumption and during this process $\mathrm{pH}$ was stabilized and oxygen reached saturation.

The cultures were kept in containers with 2 L M4 medium with each containing 45 organisms. The water was renewed twice a week, preferably on Mondays and Fridays. The micro-crustaceans were fed daily with the unicellular algae Pseudokirchneriella subcapitata with an approximate number of $10^{7}$ cells per organism (Knie and Lopes, 2004). Between the months of May and August of 2011, four water samples were collected. One sampling point was established for the Piracicaba River and one for the Itapeva Stream.

The procedures for the tests were expressed in the toxicity to the D. magna (FTD) factor that corresponds to the dilution factor (FDD) of the lower concentration that occurs in less than $10 \%$ of immobile individuals. A statistical calculation is unnecessary because the result is given directly and as an integer (ABNT, 2003; Knie and Lopes, 2004). Five concentrations were used for the final test, as shown in Table 1. Each dilution was divided into two $100 \mathrm{~mL}$ beakers, each with $50 \mathrm{~mL}$. Using Pasteur pipettes, 10 organisms were transferred to each beaker and incubated at a temperature of $20 \pm 2{ }^{\circ} \mathrm{C}$ in the dark, without food. The acute test lasted 48 hours.

Table 1. Dilution prepared for the acute toxicity test with D. magna and the corresponding dilution factor.

\begin{tabular}{cccccc}
\hline $\begin{array}{c}\text { Sample } \\
\text { dilution }\end{array}$ & $\begin{array}{c}\text { Dilution Factor } \\
\left(\mathrm{FD}_{\mathrm{D}}\right)\end{array}$ & Sample $(\mathrm{mL})$ & $\begin{array}{c}\text { Volume of water used } \\
\text { on dilution }(\mathrm{mL})\end{array}$ & $\begin{array}{c}\text { Final volume } \\
(\mathrm{mL})\end{array}$ & $\begin{array}{c}\text { Concentration of } \\
\text { test-solution }(\%)\end{array}$ \\
\hline Control & - & - & 100.0 & 100 & - \\
$1: 1$ & 1 & 100.0 & - & 100 & 100.0 \\
$1: 2$ & 2 & 50.0 & 50.0 & 100 & 50.0 \\
$1: 4$ & 4 & 25.0 & 75.0 & 100 & 25.0 \\
$1: 8$ & 8 & 12.5 & 87.5 & 100 & 12.5 \\
$1: 16$ & 16 & 6.3 & 93.8 & 100 & 6.3 \\
$1: 32$ & 32 & 3.1 & 96.9 & 100 & 3.1 \\
\hline
\end{tabular}




\section{RESULTS AND DISCUSSION}

Results for the physiochemical parameters for the Piracicaba River and the Itapeva Stream are shown in Figure 1. According to Cetesb (2007), temperature is affected daily depending on season, latitude, altitude, rate of flow and depth. Temperature rise may occur due to industrial waste and power plants as well. The analysis carried out in the Piracicaba River shows that the average temperature is $21.3^{\circ} \mathrm{C}$, while in the Itapeva Stream the average was $21.2^{\circ} \mathrm{C}$; these are considered normal values. At the Corumbataí River, studies performed by Jardim (2004) during the month of May 2003 found that the temperature ranged between 16.5 and $19.4^{\circ} \mathrm{C}$.

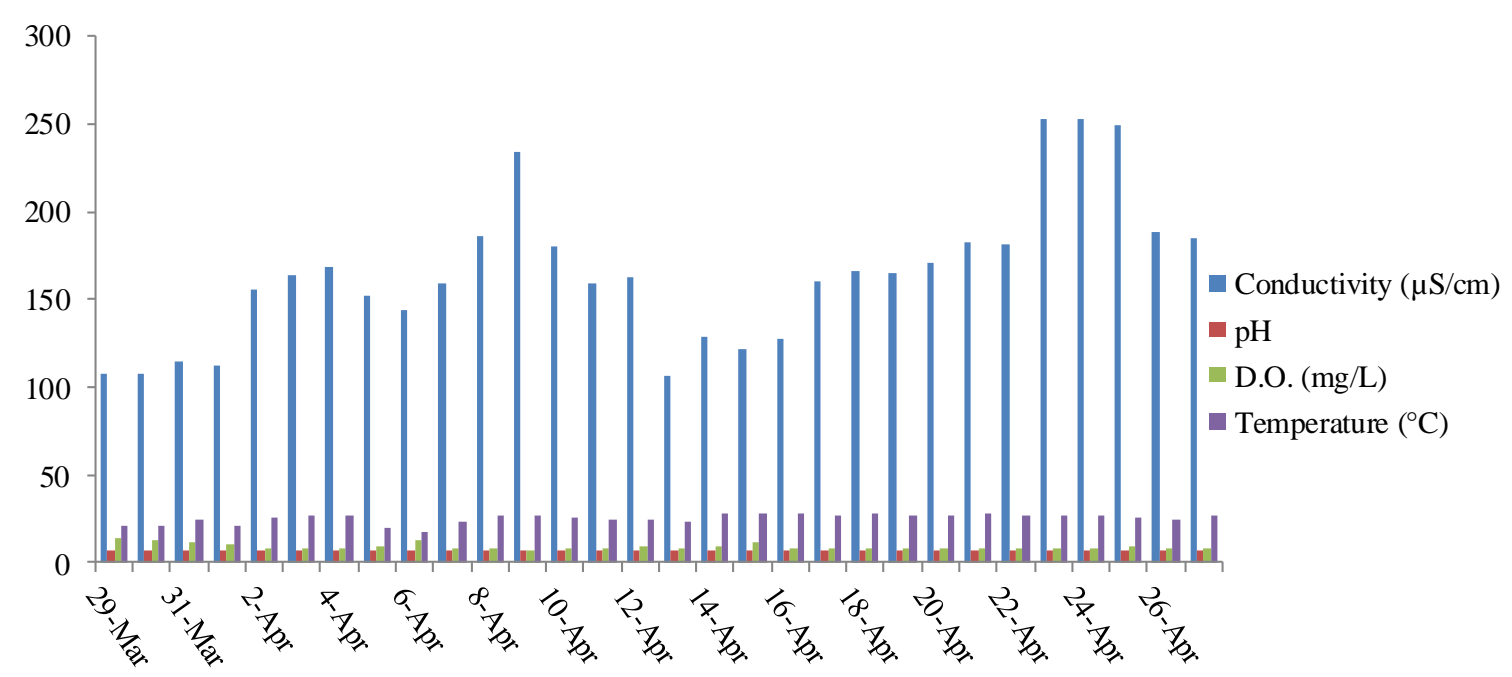

Figure 1. Conductivity, $\mathrm{pH}, \mathrm{DO}$ and temperature from collected samples from the Itapeva Stream and the Piracicaba River during the period from March to April 2013.

The lowest $\mathrm{pH}$ value for the Itapeva Stream was 6.68 in May and the highest was 7.48 in June. For the same period, the Piracicaba River $\mathrm{pH}$ ranged from 6.95 to 7.41. The CONAMA resolution 357 (CONAMA, 2005) accepts values between 6.0 and 9.0; therefore, according to the analyses, both water bodies are under acceptable conditions. According to this variable, the Corumbataí River which is a tributary to the Piracicaba River, had a $\mathrm{pH}$ ranging from 6.0 to 9.0 between April and July in the years 2001 and 2003 according to studies of Tauk-Tornisielo and Palma-Silva (2008).

A pH sample either acid or alkaline influences the conductivity of the environment. In both collection points the average $\mathrm{pH}$ was 7.2, and was therefore neutral and not interfering in conductivity (Esteves, 1988). In very pure water conductivity is low; on the other hand, the conductivity value is increased when the water is contaminated. For conductivity analysis, as shown in Table 1 , the Itapeva Stream presented values from 418.1 to $538.2 \mu{\mathrm{S} . \mathrm{cm}^{-1}}^{-}$. The Piracicaba River had observed conductivity from 187.5 to $260.1 \mu \mathrm{S} . \mathrm{cm}^{-1}$.

The results of the analyses can be explained by the level of pollutants discharged in the water body (Taulk-Tornisielo and Palma-Silva, 2008). High conductivity values for the Itapeva Stream can be explained by the large amount of organic matter and the accelerated decomposition. According to Molin et al. (2007), the stream receives effluent from household pollutants at various districts of the city. Although the Piracicaba River has a large water flow (Mortatti et al., 2004), this water body passes through many obstacles that influence the amount of organic matter, and despite receiving more sewage discharges than the Itapeva Stream, values observed on the Piracicaba River are lower. Compared to the Corumbataí River, which supplies the city of Piracicaba, the conductivity range recorded in the months of 
April and July was 50 to $250 \mu \mathrm{S} . \mathrm{cm}^{-1}$ in the years 2001 to 2003 (Tauk-Tornisielo and PalmaSilva, 2008).

According to Toniollo et al. (1996), water bodies must provide levels of dissolved oxygen (DO) near $9.2 \mathrm{mg} . \mathrm{L}^{-1}$ at a temperature of $20^{\circ} \mathrm{C}$. Higher values indicate the presence of algae and lower values the presence of organic matter. According to Esteves (1988), the factors that control the concentration of oxygen are: temperature, current, light, pressure, and organic matter. The Itapeva Stream constantly receives sewage discharges resulting in an increase of organic matter.

Levels of dissolved oxygen (DO) for the Itapeva Stream were 0.92 in July and $6.31 \mathrm{mg} . \mathrm{L}^{-1}$ in May. The average dissolved oxygen in the water body was $2.85 \mathrm{mg} . \mathrm{L}^{-1}$. Toniollo et al. (1996) notes that fish cannot survive in values equal to $2 \mathrm{mg} \mathrm{L}^{-1}$.

Higher values were measured in the Piracicaba River, $11.36 \mathrm{mg} . \mathrm{L}^{-1}$ in June and 6.89 $\mathrm{mg} . \mathrm{L}^{-1}$ in August, with an average of $8.79 \mathrm{mg} . \mathrm{L}^{-1}$. Esteves (1988) reports that daily variations in light and temperature compromise the dissolution of oxygen, mainly because this gas is involved with photosynthesis and there are periods of greater and lower photosynthetic activity in plants. In 2003, Cetesb (2007) identified OD river levels ranging from 0 to $2.0 \mathrm{mg} . \mathrm{L}^{-1}$. At the Corumbataí River, Tauk-Tornisielo and Palma-Silva (2008) recorded OD values between 0 and $9.0 \mathrm{mg} \mathrm{L}^{-1}$ in 2003 .

Table 2 shows the results of acute toxicity tests $\mathrm{FT}_{\mathrm{D}}$ in $D$. magna. In the month of May, the Itapeva Stream showed $75 \%$ immobility at a concentration of 1:1 (100\%); therefore, FTD was equal to 1 . In June, immobility was $100 \%$ at a concentration of 1:8 (12.5\%), and $\mathrm{FT}_{\mathrm{D}}$ was equal to 8. No toxicity occurred in the July sample. In August, $100 \%$ immobility was recorded at a concentration of $1: 1(100 \%)$, so the $\mathrm{FT}_{\mathrm{D}}$ was equal to 1 . According to the eco-toxicological tests, the Itapeva Stream is unfit for aquatic life. The Piracicaba River showed no toxicity in any of the months; this may be a result of the dilution the effluents undergo, since the water capacity is larger than that of the Itapeva Stream.

Table 2. Toxicity Factor $\left(\mathrm{FT}_{\mathrm{D}}\right)$ obtained in acute tests with $D$. magna in the Itapeva Stream and the Piracicaba River.

\begin{tabular}{lcccc}
\hline & \multicolumn{2}{c}{ Itapeva Stream } & & Piracicaba River \\
\cline { 2 - 3 } Months & $\begin{array}{c}\text { Concentration } \\
(\%)\end{array}$ & $\mathrm{FT}_{\mathrm{D}}$ & & $\mathrm{FT}_{\mathrm{D}}$ \\
\hline May & 100.0 & 1 & \\
June & 12.5 & 8 & - \\
July & 0.0 & - & - \\
August & 100.0 & 1 & - \\
\hline
\end{tabular}

The results of toxicity tests may be influenced by several factors: the availability of nutrients in greater amounts than toxic agents, the resistance of $D$. magna to the concentration of pollutants or household effluents with high loads of nutrients and microorganisms serving as food for organisms (Salonem and Hammar 1986; Esteves, 1988). In the studies of Jardim (2004) with D. magna at the Corumbataí River, toxicity was observed in some urbanized areas, which were upstream of Analândia, upstream of the Corumbataí River and upstream of Rio Claro.

The trophic state index was determined by analysis of chlorophyll $\alpha$, as shown in Table 3. The Piracicaba River in the months of May, June and July appeared as mesotrophic, and in August, it was classified as eutrophic. In May, the Itapeva Stream was classified as ultra-oligotrophic; in June, it was classified as oligotrophic; and in July and August as mesotrophic. 
Table 3. Trophic Index State (IET) and river classification categories at the Piracicaba River and the Itapeva Stream.

\begin{tabular}{lccccc}
\hline \multirow{2}{*}{ Months } & \multicolumn{2}{c}{ Piracicaba River } & & \multicolumn{2}{c}{ Itapeva Stream } \\
\cline { 2 - 3 } \cline { 5 - 6 } \cline { 5 - 6 } May & IET & Category & & IET & Category \\
June & 57.93 & Mesotrophic & & 43.17 & Ultraoligotrophic \\
July & 56.19 & Mesotrophic & & 49.17 & Oligotrophic \\
August & 60.02 & Eutrophic & & 58.68 & Mesotrophic \\
\hline
\end{tabular}

Values of EIT for the Piracicaba River in the first three months and for the Itapeva Stream in the fourth month, according to CETESB (2007), are acceptable but undesirable. In August, the Piracicaba River was classified as eutrophic, i.e., reflects the influence of anthropogenic activities to undesirable levels and which compromise its use. The Itapeva is an underground stream, so the absence of light prevents the growth of algae and does not allow analysis of chlorophyll $\alpha$ for an EIT determination.

Artificial eutrophication involves human activities. This process results from the discharge of pollutants from various origins: agricultural, industrial and domestic waste. Fertilizers that are washed into the river by rain or soil drainage are a main form of discharge, as well as chemical substances discarded from industrial processes. Detergents and human waste enrich the medium with nitrogen and phosphorus causing eutrophication which promotes the growth of many organisms. Contributing to the imbalance of the ecosystem, this process produces more organic matter than is necessary for the decomposers (TUNDISI and TUNDISI, 2008; Esteves, 1988).

\section{CONCLUSIONS}

Eco-toxicological tests showed that the Itapeva Stream presents toxicity, and that the Piracicaba River had no toxicological effects on test organisms. From the analysis of chlorophyll $\alpha$, the Piracicaba River and the Itapeva Stream are in eutrophic states. The $\mathrm{pH}$ and temperature of both water bodies are normal, since the analyses show that the conductivity values were higher than desirable. The Piracicaba River carries a high level of dissolved oxygen, while in the Itapeva Stream oxygen is below that required for the maintenance of aquatic life. In the Itapeva Stream analyses, the use of chlorophyll $\alpha$ is not feasible in studies of eutrophication, since the stream runs underground and there is no passage of light, and therefore no algae growth can occur.

\section{ACKNOWLEDGEMENTS}

The authors are grateful to CNPq, CAPES and FAPESP for their financial support.

\section{REFERENCES}

ASSOCIAÇÃO BRASILEIRA DE NORMAS TÉCNICAS. NBR 12.713: Ecotoxicologia aquática-Toxicidade aguda - Método de ensaio com Daphnia spp. (Cladocera, Cristacea). Rio de Janeiro, 2003 ${ }^{\mathrm{a}} .16$ p.

Associação Brasileira de Normas Técnicas. NBR/ISO IEC 17.025: Requisitos gerais para competências de laboratórios de ensaio e calibração. Rio de Janeiro, 2001. 20p. 
Companhia de Tecnologia de Saneamento Ambiental. Relatório de qualidade das águas do estado de São Paulo - 2007. Anexo III: Índices de qualidade das águas. São Paulo: 2007. 14p.

COMPANHIA BRASILEIRA DE PROJETOS E EMPREENDIMENTOS. Plano das bacias hidrográficas dos rios Piracicaba, Capivari e Jundiaí 2010 a 2020: relatório síntese. São Paulo, 2011.

CONSELHO NACIONAL DO MEIO AMBIENTE - (Brasil). Resolução n 357/2005 de 17 de março de 2005. Diário Oficial [da] União, n. 53, p. 58-63, 18 mar. 2005.

ELENDT, B. P.; BIAS, W. R. Trace nutrient deficiency in Daphnia magna cultured in standard medium for toxicity testing. Effects of the optimization of culture conditions on life history parameters of Daphnia magna. Walter Research, New York, v. 24, n. 9, p. 11567-11576, 1990. http://dx.doi.org/10.1016/0043-1354(90)90180-E

ESTEVES, F. A. Fundamentos em limnologia. Rio de Janeiro: Interciência, 1988.

JARDIM, G. M. Estudos Ecotoxicológicos da Agua e do sedimento do rio Corumbatai, SP. 2004. 126 f. Dissertação (Mestrado em ecologia de agrossistemas) - Escola Superior de Agricultura Luiz de Queiroz, Universidade de São Paulo, Piracicaba, 2004.

KNIE, L. W. J.; LOPES, E. W. B. Testes ecotoxicológicos - Métodos, técnicas e aplicações. Florianópolis: FATMA: GTZ, 2004. p.289.

MARANHO, L. A.; NIEWEGLOWSKI, A. M. A. Influência da dureza da água no estudo da reprodução de Daphnia magn. Pesticidas: Revista Técnico Cientifica, Curitiba, v. 5, n. 5, p. 33-52, 1995. http://dx.doi.org/10.5380/pes.v5i0.39394

MOLIN, P. G.; COUTO, H. T. Z.; SILVA FILHO, D. F. Uso de videografia multiespectral aérea para quantificar o uso de solo em uma microbacia hidrográfica urbana. In: SIMPÓSIO INTERNACIONAL DE INICIAÇÃO CIENTIFICA DA USP, 15., 2007, Pirassununga. Anais... São Paulo: USP, 2007. v. 1. p. 4603-4603.

MORTATTI, J. et al. Hidrologia dos rios Tiete e Piracicaba: series temporais de vazão e hidrogramas de cheia. Revista Ciência e Tecnologia, Piracicaba, v. 12, n. 23, pg. 55-67, 2004.

SALONEM, K.; HAMMAR, T. On the importance of dissolved organic matter in the nutrition of zooplankton in some lake Waters. Oecologia, Berlin, v. 68, p. 246-253, 1986.

TAUK-TORNISIELO, S. M.; PALMA SILVA, G. M. Aspectos gerais da bacia do rio Corumbatai. In: TAUK-TORNISIELO, S. M.; ESQUIERRO, J. C. (Orgs.). Bacia do rio Corumbatai: aspectos socioeconômicos e ambientais. Rio Claro: Consórcio PCJ, 2008. p. 7-16.

TONIOLlO, V.; LOYOLA, R. G. N.; POZZOBON, M. G. G. Curso de limnologia básica. Joinville: UNIVILLE, 1996. Vol. 1.

TUNDISI, J. G.; TUNDISI, T. M. Limnologia. São Paulo: Oficina de Textos, 2008.

ZAGATTO, P. A.; BERTOLETTI, E. Ecotoxicologia Aquática: princípios e aplicações. São Carlos: RIMA, 2006. 